\title{
Physical and chemical characteristics of cashew nut flour stored and packaged with different packages
}

\author{
Bruna Carolina GADANI ${ }^{1}$, Kelly Márcia Lazarotto MILÉSKI ${ }^{1}$, Lucas Silva PEIXOTO ${ }^{1}$, Juliana da Silva AGOSTINI ${ }^{1 *}$
}

\begin{abstract}
The aim of this study was to evaluate the physical and chemical changes in cashew nut flour under different packaging and storage conditions. The flour samples were characterized according to their chemical composition, packaged in polystyrene trays associated with covering chloride polyvinyl (PVC), plastic pot of polyethylene terephthalate (PET), plastic packaging polyethylene (POL) and without coating polystyrene trays (CON). All packages were stored for 225 days, evaluating every 45 days the moisture content of the flour as well as extracting their oil by the cold method for characterization on the following indexes: acidity, saponification, iodine, peroxide and refraction. There was slight and gradual increase in the moisture content from the $45^{\text {th }}$ to the $225^{\text {th }}$ day, especially for products packaged in PVC and without coating polystyrene trays (CON). The oil saponification indexes showed gradual decrease during storage, especially in flour without packaging (CON). There was a gradual increase in the iodine index until the $135^{\text {th }}$ day, followed by decay. The acidity and peroxide indexes increased along with the storage time. However packages with lower oxygen and moisture permeability, such as PET and POL, minimized such changes, being therefore the most suitable for long-term storage.
\end{abstract}

Keywords: deterioration; rancidity; Anacardium occidentale L.; oilseed; oil.

Practical Application: definition of better packaging and maximum storage time for cashew nut flour.

\section{Introduction}

Cashew nut, one of the most important edible nuts in the international trade, is the fruit of cashew trees (Anacardium occidentale L.), and its kernel is the most widely industrialized cashew product (Pinto et al., 2015; Soares et al., 2012a). The real fruit of the cashew is commonly a nut, composed of kernel and pericarp or shell. The kernel is slightly curved back on itself and forms two cotyledons, representing about $20-25 \%$ of the nuts weight. It is wrapped in a thin and hard removing peel, which is about $5 \%$ of the whole nut (Ogunwolu et al., 2009). Cashew nuts are globally consumed for their desirable nutritional and sensory attributes, being good source of proteins ( 20\%), carbohydrates $(\sim 23 \%)$, and fats ( 45\%) (Das et al., 2014).

Because of its excellent nutritional characteristics and technologies involved in its processing, the cashew are a high value added product, being marketed as whole almonds, designed especially for the foreign market, or fragmented and broken, used in the internal market industries of ice cream, cakes and chocolates (Kross, 2008). It is an important delicacy, which is mainly used in confectionery and as a dessert nut, such as cakes, pastries, candies and chocolates, by enriching their taste and appearance (Ogunwolu \& Akinwale, 2003; Araújo \& Ferraz, 2006). In the form of flour, cashew is especially used to prepare cereal bars, cookies, candies, chocolates, etc. (Lima, 1997).

The nutritional and sensory quality of a food is related to its chemical, physical and biological factors (microbiological and enzymatic), from its manufacture to its consumption and hence information about the stability and the main characteristics of the raw materials can contribute to increase the use and improve the quality of the product.

Shelf life is related to food quality and it is most influenced by several factors such as the exposure to light and heat, transmission of gases, humidity, mechanical stresses, and contamination by microorganisms for example. Product quality is often mathematically adjusted around a single parameter (concentration of a chemical compound, a microbiological index, or a physical parameter), although this approach can lose relevance (Irtwange \& Oshodi, 2009).

Foods with low moisture content and high percentage of fat such as cashew nuts become vulnerable to deterioration such as oxidation and moisture absorption reactions, which leads to microbiological changes, texture and loss of crispness (Lima, 1997; Lima et al., 2004; Lima \& Borges, 2004). Cashew nut is also vulnerable to deterioration over time and this result goes from improper packaging to adverse storage conditions. The rate of spoilage is dependent on the moisture content of the stored nuts, relative humidity of the storage environment, permeability of packaging material, room temperature and insect infestation. According to Irtwange \& Oshodi (2009), roasted cashew nuts deteriorate mainly by mould growth, rancidity and insect attack.

The rancidity characterized by deteriorative reactions that affect food fatty acids can be classified according to their nature, as hydrolytic and oxidative. The hydrolytic rancidity occurs 
by means of lipase enzymes present in the food. The oxidative rancidity can occur enzymatically, in which lipoxygenase enzymes are used, or by non-enzymatic means through autoxidation reactions or photooxidation (Bakkalbaşi et al., 2011; Gamli \& Hayoglu, 2007; Lima, 1997).

Since lipids constitute more than $40 \mathrm{~g} \cdot 100 \mathrm{~g}^{-1}$ of cashew nut kernels (Chandrasekara \& Shahidi, 2011), lipid oxidation is their main cause of deterioration, due to the formation of off-flavors (oxidative rancidity), which impairs their acceptability (Pinto et al., 2015). These oxidative reactions are important in a way that we can establish the shelf life of many food products (Soares et al., 2012b). Moreover, there is solid evidence wich indicates that free radicals cause oxidative damage to lipids, proteins and nucleic acids. Nuts contain many different antioxidative components apart from vitamin $A$, vitamin $C$ and $\beta$-carotene. Nuts are also known to contain antioxidant phytochemicals such as flavonoids, phenolic compounds, luteolin, tocotrienols, isoflavones, ellagic acid as well as other components like plant sterols (Rainey \& Nyquist, 1997; Sajilata \& Singhal, 2006).

Taking into account the damage arising from these reactions, the use of packaging to minimize permeability to oxygen and moisture are viable alternatives to minimize reactions during the storage period, thereby ensuring a longer shelf time. The packaging material used must be appropriate and specific to comply with food preservation criteria and nutrients, as well as avoiding the action of environmental factors such as light, moisture, oxygen and microorganisms, preventing or hindering thus the contact between the external environment and the product inside. Furthermore, the packaging assures the integrity of the product during transport and storage (Robertson, 1993; Sarantópoulos et al., 2002).

Sometimes the kernels are sold in a bulk, not protected by an external package while exposed due to be seen by consumers, so in that case the presence of a protective coating would be especially useful. Another possibility is that the application of coating in cashew nut kernels could significantly increase their stability, avoiding the need of using high barrier packaging materials (more expensive and usually thicker) (Pinto et al., 2015).

The main factors that determine the shelf life of processed foods are: type of food, the degree of destruction or microbial inactivation achieved by control of hygiene process during processing and packaging, barrier properties of packaging materials and the temperature during the processes and distribution/transportation package (Adebajo \& Diyaolu, 2003). For packaging, the main factors affecting shelf life are: the size of package according to the volume, the atmospheric condition which the package is required to with stand during transportation and before its use, and the overall package resistance to moisture, atmospheric gases and odours, including the closures and folded areas (Dwem, 1997).

The preservation of the original characteristics of the food as long as possible after processing is one of the goals of the food industries. Storage conditions and the type of packaging used are great relevance, and for this reason it should be analyzed in order to define the most suitable conditions to maintain quality during shelf life (Matta et al., 2004). Due to the economic influence of cashews, large losses as a result of deterioration, the search for a better characterization of raw materials and the need to improve packaging options for food preservation, the aim of this study was to analyze the effect of the type of the packaging material and time on the spoilage rate under environmental conditions with a view to making recommendations based on the result of the experiment.

\section{Materials and methods}

\subsection{Raw material}

The cashew flour was acquired from a cooperative in the northern region of Mato Grosso, Brazil. Flours were produced from dehulled cashew kernels, ground in the mill, passed through sieves of $0.5 \mathrm{~mm}$ and toasted in pan.

\subsection{Determination of the proximate composition of cashew nuts meal}

Flours received from the cashew industry were initially submitted to the determination of the proximate composition (Instituto Adolfo Lutz, 2008). Moisture was measured by gravimetric method using heat loss on drying at $105^{\circ} \mathrm{C}$ until constant weight; the fixed mineral residue (ash) was determined by calcination in muffle furnace set at $550^{\circ} \mathrm{C}$ to constant weight; protein fraction was obtained by determining the percentage of the total nitrogen content of the sample according to the Kjeldahl method and multiplied by the factor 5.18, recommended for almonds; the lipid fraction was determined by continuous hot extraction by the Soxhlet method, preceded by acid hydrolysis, using petroleum ether as solvent extractor.

\subsection{Packaging and storage of cashew nut meal}

Samples of cashew flour, in a quantity of $120 \mathrm{~g}$, were packed in one of the following material types: 1) polystyrene trays associated with polyvinyl film coating (PVC); 2) plastic pot of polyethylene terephthalate (PET); 3) plastic packaging polyethylene (POL); and 4) polystyrene trays without covering, considered as the control test (CON). The properly packed samples were stored for 225 days at ambient condition. Products in their intact containers were removed from storage and subjected to physical and chemical evaluations at 45 -day intervals, started from the time 0 , totaling 6 evaluation periods $(0,45,90,135$, 180 and 225 days of storage) .

\subsection{Physical and chemical determinations of stored cashews flour}

In order to investigate the stability of the stored product, samples of cashew nuts meal were subjected, after each storage period, to determination of the moisture content (Instituto Adolfo Lutz, 2008), oil extraction by cold method of Bligh \& Dyer (1959) with adjustments developed by Lima (1997) and oil characterization, such as the saponification, iodine, acidity, peroxide and refraction index (Instituto Adolfo Lutz, 2008). 


\subsection{Experimental design and data analysis}

The experiment was conducted in a completely randomized design in a factorial $4 \times 6$, composed of four types of packaging materials (including the control group), and six periods of evaluations (including the time 0), in triplicate .

The data were submitted to analysis of variance (ANOVA) and the interaction between the packaging and storage time factors were subjected to regression analysis. The minimum coefficient of determination $\left(\mathrm{R}^{2}\right)$ considered to fit the curves was 0.50 . In case there were no significance or adjustment curves, the values were represented by the mean and coefficient of variation. Comparisons between the packages were performed by Tukey test at $5 \%$ probability.

\section{Results and discussion}

The cashew nut flour used in the present study had average levels of moisture, ash, fat and protein $3.1 \pm 0.3,2.6 \pm 0.0,56 \pm 8.5$, $16.5 \pm 0.5 \mathrm{~g} .100 \mathrm{~g}^{-1}$, respectively. The sample evaluated showed high levels of lipids and proteins, and the proximate composition similar to the results observed by Lima et al. (2004) e Melo et al. (1998). The high fat content observed in cashew nuts associated with a high proportion of unsaturated fatty acids composition, represented mostly (about $80 \%$ ) by oleic and linoleic acids (Lima et al., 2004; Toschi et al., 1993) predispose the deteriorative reactions of lipid oxidation during processing and storage, which can make food sensorially unacceptable and produce potentially toxic substances (Soares et al., 2012b).

The moisture content of the stored cashew flour had a slight increase from day 45 , which persisted up to day 225 . This increase was more pronounced in products packaged in $\mathrm{PVC}$ and CON, mainly due to their higher relative humidity conditions of the local air during the storage period and low permeability characteristics of PVC packaging (Figure 1a). Zuniga et al. (2011) verified that integral biscuits (snacks) made from cashew nut packaged in plastic packaging increased the moisture content over 80 days of storage and attributed such behavior to the conditions of high relative humidity of the storage site.

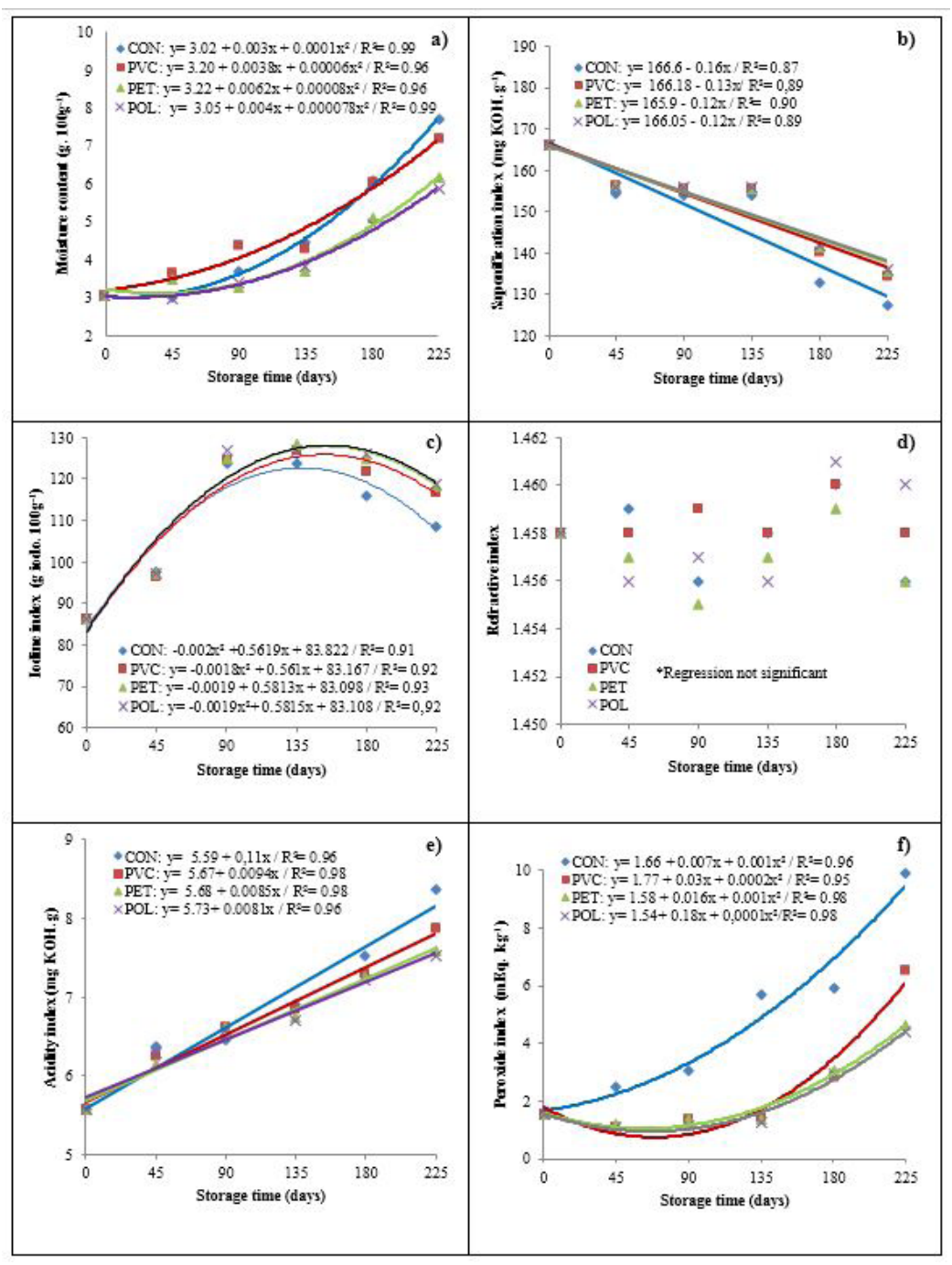

Figure 1. Moisture content (a) of stored cashew nut flour and indices of saponification (b), iodine (c), refractive (d), acidity (e) and peroxide (f) of oil from stored cashew nut flour coated with different containers. PVC: polystyrene trays associated with covering chloride polyvinyl; PET: plastic pot polyethylene terephthalate; POL: plastic packaging polyethylene; CON: without coating polystyrene trays. 
There was an increase of the moisture content of the stored flour, which was more pronounced in PVC products package (Table 1) compared to those packed in PET and POL (Table 1). The PVC film showed greater permeability to water vapor (Finger \& Vieira, 1997) and oxygen (Silva et al., 2003).

It is noteworthy that some PVC samples were attacked by insects, once they broke the protective film. This was observed after 90 days of storage, with occasional breakage of the package, exposing the sample to interferences.

The factor packaging and a significant interaction time $\mathrm{x}$ packaging affected the saponification index (Figure 1b), with lower values during storage observed in all packaging treatments, especially in the flour without packaging (CON). The saponification index of neutral glycerides varies with the nature of the constituent fatty acids, i.e., the lower the molecular weight the greater the saponification number will be (Moretto \& Fett, 1998). Therefore, this parameter analyzed separately helps to identify than to determine feasible degradation in the samples. In a study carried out with crude pequi oil, Brasil et al. (2011) observed a decrease in the saponification index showing that with the course of time the food quality oil decayed. According to Ribeiro et al. (2012), the decrease in the saponification value and increase in the levels of acidity and peroxide value of the pequi oil obtained by mechanical extraction indicates the occurrence of fatty acid hydrolysis reactions during storage.

There was no significant influence of type of packing material on the iodine index; however, there was a gradual increase in the values until the $135^{\text {th }}$ day, regardless the used coating condition; after this period, a decrease in the values until day 225 was observed (Figure 1c). To evaluate the stability of Brazil nuts, Kross (2008) found small changes in chain fatty acids in their samples, but the iodine index showed a gradual decrease at the end of the storage period. The iodine number is an empirical test that indicates the degree of unsaturation of the oil (Jorge \& Luzia, 2012). Ribeiro et al. (1993) observed no major changes in the fatty acids chains of Brazil nuts stored for four months, although there was a gradual decrease, and the peeled chestnuts showed lower values in these indexes, which were explained to a great extent by the process of oxidative deterioration process occurred in these products. According to Sanibal \& Mancini (2002) this decrease can be attributed to the destruction of double bonds by oxidation process, section and polymerization.

Concerning the refractive index, we observed oscillations of the values (Figure 1d), and the data did not fit with any

Table 1. Effect of type of packaging material on the average moisture content of cashew flour.

\begin{tabular}{cc}
\hline Packaging & Moisture content $\left(\mathrm{g} .100 \mathrm{~g}^{-1}\right)^{\star}$ \\
\hline CON & $4.7 \pm 1.8 \mathrm{a}$ \\
PET & $4.1 \pm 1.1 \mathrm{~b}$ \\
PVC & $4.8 \pm 1.4 \mathrm{a}$ \\
POL & $4.0 \pm 1.1 \mathrm{~b}$ \\
\hline
\end{tabular}

${ }^{*}$ The averages followed by the same letter do not differ significantly by Tukey test at $5 \%$ probability. PVC: polystyrene trays associated with covering chloride polyvinyl; PET: plastic pot polyethylene terephthalate; POL: plastic packaging polyethylene; CON: without coating polystyrene trays. mathematical model. The results are in agreement with the values found by Kross (2008), which were 1.4615. This index increases proportionally with the amount of hydrogenated chain as well as the degree of unsaturation of constituent free fatty acids of the glycerides.

There were no significant effects of the conditions of packaging nor interaction time $\mathrm{x}$ packing in acidity values. However a linear increase in this index over the storage up to $50.36 \%$ was observed (Figure 1e), suggesting the occurrence of hydrolytic rancidity and formation of free fatty acids. Such reaction involves lipid hydrolysis by lipases, phospholipases and peroxidase enzymes present in grains tissues or produced by the associated microorganisms (Zadernowskl et al., 1999; Alencar et al., 2010). Lima \& Bruno (2007) also observed a tendency to increase the acidity index in pastes prepared with cashew nuts stored for 300 days. Zuniga et al. (2011) found that the acidity of integral biscuits (snacks) made from cashew nut increased substantially only at 80 days of storage. Regarding the peroxide value (Figure 1f), there was an effect of the coating condition and storage period. Samples of all treatments showed an increased on this index after 90 days of storage; especially the control samples (CON), which had significantly high levels throughout the storage period, and PVC, with a significant increase in comparison with the POL and PET, in 225 days of storage. Peroxide content is a common parameter to characterize oils and fats, since its values indicate high degradation and oxidation of them. The lipid oxidation reactions are the main cause of deterioration of oils and fats and develop from the interaction of unsaturated fatty acids and oxygen with subsequent formation of peroxides which can be converted to secondary and stable products such as aldehydes, ketones, alcohols, hydrocarbons, esters, furans and lactones, which alter the physical and chemical properties and impact negatively on the taste and odor of food (Santos, 2007; Farhoosh et al., 2009; Alencar et al., 2010).

The increased stability of products packed with either POL or PET is explained by the fact that these materials are effective barriers to gas permeability and water vapor (Azeredo et al., 2012; Freire et al., 1998).

A product with a peroxide index between 1 and 5 meq $\mathrm{kg}^{-1}$ is classified at low oxidation state; that between 5 and 10 meq kg-1 at moderate oxidation, and above $10 \mathrm{meq} \mathrm{kg}^{-1}$ is classified at high oxidation state (Alencar et al., 2010). Thus, the products of our study were not considered to have high peroxide indexes within the rated storage time. Lima \& Borges (2004) found an increase in this index in roasted unsalted and salty almonds up to 150 days of storage, regardless the packaging used in the treatments. Peroxide index ranged from 8.2 to 26 meq. $1,000 \mathrm{~g}^{-1}$ and 10 to 27 meq. $1,000 \mathrm{~g}^{-1}$ of oil for roasted unsalted and salty almonds, respectively.

When evaluating the stability of cashew almond paste, Lima \& Bruno (2007) observed that the average value of the acid index oscillated around $2.0 \mathrm{mEq} \mathrm{NaOH} 0.1 \mathrm{~N} .100 \mathrm{~g}^{-1}$, which was considered low. Furthermore, there was an increasing trend in all formulations over 300 days, suggesting that this finding is the beginning of hydrolytic reactions in the paste. Nagaraja (2003) also assessed the chemical quality formulations of cashew nut pastes. However even though the products were stored at $8{ }^{\circ} \mathrm{C}$ 
for six months in the latter study, an increasing trend of acid index was also observed, with values reaching up to $18.6 \mathrm{mEq}$ $\mathrm{NaOH} 0.1$ N. $100 \mathrm{~g}^{-1}$.

\section{Conclusions}

Since the cashew nut flour is rich in lipids that can undergo oxidation and rancidity reactions, the results of the present study showed that from almost all the physico-chemical patterns of the samples have undergone to significant changes in their values, resulting in variations from the initial conditions in the samples, even before storage.

Plastic pot polyethylene terephthalate (PET) and plastic packaging polyethylene (POL) showed the most satisfactory results among the studied packaging materials, which reflect therefore in greater shelf life of the tested product on the market.

\section{Acknowledgements}

To Conselho Nacional de Desenvolvimento Científico e Tecnológico (CNPq) for the scholarship.

\section{References}

Adebajo, L. O., \& Diyaolu, S. A. (2003). Mycology and spoilage of retail cashew nuts. African Journal of Biotechnology, 2(10), 369-373. http:// dx.doi.org/10.5897/AJB2003.000-1076.

Alencar, E. R., Faroni, L. R. D., Peternelli, L. A., Silva, M. T. C., \& Costa, A. R. (2010). Influence of soybean storage conditions on crude oil quality. Revista Brasileira de Engenharia Agrícola e Ambiental, 14(3), 303-308. http://dx.doi.org/10.1590/S1415-43662010000300010.

Araujo, M. C., \& Ferraz, A. C. O. (2006). Efeito da umidificação, tratamento térmico e deformação sobre a decorticação da castanha de caju 'CCP-76' por meio de impacto único e direcionado. Engenharia Agrícola, 26(2), 590-599. http://dx.doi.org/10.1590/ S0100-69162006000200029.

Azeredo, H. M. C., Brito, E. S., \& Garruti, D. S. (2012). Embalagens e suas interações com os alimentos (2. ed.). Brasília: Embrapa.

Bakkalbaşi, E., Yilmaz, O. M., Javidipour, I., \& Artik, N. (2011). Effects of packaging materials, storage conditions and variety on oxidative stability of shelled walnuts. LWT - Food Science and Technology (Campinas.), 46, 203-209.

Bligh, E. G., \& Dyer, W. J. (1959). A rapid method of total lipid extraction and purification. Canadian Journal of Biochemistry and Physiology, 37(8), 911-917. PMid:13671378. http://dx.doi.org/10.1139/o59-099.

Brasil, R. V., Cavallieri, A. L. F., Costa, A. L. M., \& Gonçalves, M. A. B. (2011). Caracterização física e química do óleo de pequi exposto a diferentes condições de armazenamento. In $8^{\circ}$ Congresso de Pesquisa, Ensino e Extensão - Conpeex, Goiânia, Brazil. Retrieved from: http://www.sbpcnet.org.br/ livro/63ra/conpeex/pibic/trabalhos/ RENATA_V. PDF

Chandrasekara, N., \& Shahidi, F. (2011). Antioxidative potential of cashew phenolics in food and biological model systems as affected by roasting. Food Chemistry, 129(4), 1388-1396. http://dx.doi. org/10.1016/j.foodchem.2011.05.075.

Das, I., Shah, N. G., \& Kumar, G. (2014). Cashew nut quality as influenced by microwave heating used for stored grain insect control. International Journal of Food Science, 2014, 1-7. PMid:26904638. http://dx.doi.org/10.1155/2014/516702.
Dwem, N. N. (1997). Storage stability of roasted groundnuts and bambara nuts at various relative humidities (40 p., Unpublished B. Eng Project). Makurdi: University of Agriculture.

Farhoosh, R., Einafshar, S., \& Sharayei, P. (2009). The effect of commercial refining steps on the rancidity measures of soybean and canola oils. Food Chemistry, 115(3), 933-938. http://dx.doi.org/10.1016/j. foodchem.2009.01.035.

Finger, F. L., \& Vieira, G. (1997). Controle da perda pós-colheita de água em produtos hortícolas (29 p., Caderno didático, 19). Viçosa: UFV.

Freire, M. T. A., Reyes, F. G. R., \& Castle, L. (1998). Estabilidade térmica de embalagens de poli (tereftalato de etileno (PET): determinação de oligômeros. Polímeros, 8(1), 46-53.

Gamli, F. O., \& Hayoglu, I. (2007). The effect of the different packaging and storage conditions on the quality of pistachio nut paste. Journal of Food Engineering, 78(2), 443-448. http://dx.doi.org/10.1016/j. jfoodeng.2005.10.013.

Instituto Adolfo Lutz - IAL. (2008). Métodos físico-químicos para análise de alimentos. São Paulo: IAL. Retrieved from http://www.crq4.org. br/sms/files/file/analisedealimentosial_2008.pdf

Irtwange, S. V., \& Oshodi, A. O. (2009). Shelf-life of roasted cashew nuts as affected by relative humidity, thickness of polythene packaging material and duration of storage. Research Journal of Applied Sciences, Engineering and Technology, 1(3), 149-153.

Jorge, N., \& Luzia, D. M. M. (2012). Caracterização do óleo das sementes de Pachira aquatica Aublet para aproveitamento alimentar. Acta Amazonica, 42(1), 149-156. http://dx.doi.org/10.1590/S004459672012000100017.

Kross, R. K. (2008). Processamento de amêndoas de castanha de caju: secagem, extração e estabilidade do azeite (Tese de doutorado). Universidade Federal de Campina Grande, Campina Grande.

Lima, A. C., Garcia, N. H. P., \& Lima, J. R. (2004). Obtenção e caracterização dos principais produtos do caju. Boletim CEPPA, 22(1), 133-144.

Lima, J. R. (1997). Avaliação da estabilidade de amêndoas de castanha de caju fritas e salgadas acondicionadas em embalagens flexíveis de diferentes propriedades de barreira (Tese de doutorado). Universidade Estadual de Campinas, Campinas.

Lima, J. R., \& Borges, M. F. (2004). Armazenamento de amêndoas de castanha de caju: influência da embalagem e da salga. Revista Ciência Agronômica, 35(1), 104-109.

Lima, J. R., \& Bruno, L. M. (2007). Estabilidade de pasta de amêndoa de caju. Ciência e Tecnologia de Alimentos, 27(4), 816-822. http:// dx.doi.org/10.1590/S0101-20612007000400023.

Matta, V. M., Cabral, L. M. C., \& Silva, L. F. M. (2004). Suco de acerola microfiltrado: avaliação da vida-de-prateleira. Ciência e Tecnologia de Alimentos, 24(2), 293-297. http://dx.doi.org/10.1590/S010120612004000200023.

Melo, M. L. P., Maia, G. A., Silva, A. P. V., Oliveira, G. S. F., \& Figueiredo, R. W. (1998). Caracterização físico-química da amêndoa da castanha de caju (Anacardium occidentale l.) crua e tostada. Ciência e Tecnologia de Alimentos, 18(2), 184-187.

Moretto, E., \& Fett, R. (1998). Tecnologia de óleos e gorduras vegetais na indústria de alimentos. São Paulo: Livraria Varella.

Nagaraja, K. V. (2003). Preparation of spread from cashew kernel baby bits. Journal of Food Science and Technology, 40(3), 337-339.

Ogunwolu, S. O., \& Akinwale, T. O. (2003). Production and nutritional composition of non convectional chocolate products in the tropics. Journal of Nutrition \& Food Sciences, 33, 120-124.

Ogunwolu, S. O., Henshaw, F. O., Mock, H., Santros, A., \& Awonorin, S. O. (2009). Functional properties of protein concentrates and 
isolates produced from cashew (Anacardium occidentale L.) nut. Food Chemistry, 115(3), 852-858. http://dx.doi.org/10.1016/j. foodchem.2009.01.011.

Pinto, A. M. B., Santos, T. M. P., Caceres, C. A., Lima, J. R., Ito, E. N., \& Azeredo, H. M. C. (2015). Starch-cashew tree gum nanocomposite films and their application for coating cashew nuts. LWT - Food Science and Technology (Campinas.), 62, 549-554.

Rainey, C., \& Nyquist, L. (1997). Nuts: nutrition and health benefits of daily use. Nutrition Today, 32(4), 157-163. http://dx.doi. org/10.1097/00017285-199707000-00006.

Ribeiro, M. A. A., Regitano-D’arce, M. A. B., Lima, U. A., \& Baggio, C. E. (1993). Armazenamento da castanha do Pará com e sem casca: efeito da temperatura na resistência ao ranço. Scientia Agricola, 50(3), 343-348. http://dx.doi.org/10.1590/S0103-90161993000300004.

Ribeiro, M. C., Vilas Boas, E. V. B., Riul, T. R., Pantoja, L. M., Marinho, H. A., \& Santos, A. S. (2012). Influence of the extraction method and storage time on the physicochemical properties and carotenoid levels of pequi (Caryocar brasiliense Camb.) oil. Ciência e Tecnologia de Alimentos, 32(2), 386-392. http://dx.doi.org/10.1590/S010120612012005000053

Robertson, G. L. (1993). Food packaging: principles and practice (680 p.). New York: Marcel Drekker.

Sajilata, M. G., \& Singhal, R. S. (2006). Effect of irradiation and storage on the antioxidative activity of cashew nuts. Radiation Physics and Chemistry, 75(2), 297-300. http://dx.doi.org/10.1016/j. radphyschem.2005.07.004.

Sanibal, E. A. A., \& Mancini, J. Fo. (2002). Alterações física, químicas e nutricionais de oleos submetidos ao processo de fritura. Food Ingredients South America, 1(3), 64-71.
Santos, E. M. (2007). Avaliação da estabilidade oxidativa de óleo de soja contendo concentrações contrastantes de ácido linolênico, durante o processamento (Dissertação de mestrado). Universidade Federal de Viçosa, Viçosa.

Sarantópoulos, C. I., Oliveira, M. L., Coltro, L., Vercelino, A. R. M., \& Corrêa, G. E. E.(2002). Embalagens plásticas flexíveis, principais polímeros e avaliação de propriedades. Campinas: CETEA/ITAL.

Silva, P. S., Soares, N. F. F., Geraldine, R. M., Puschmann, R., Oliveira, E., \& Carnelossi, M. (2003). Uso de absorvedor de oxigênio na conservação de folhas de couve minimamente processada. Revista Ceres, 50(288), 191-202.

Soares, D. J., Cavalcante, C. E. B., Cardoso, T. G., Figueiredo, E. A. T., Maia, G. A., Sousa, P. H. M., \& Figueiredo, R. W. (2012a). Estudo da estabilidade de amêndoas de castanha de caju obtidas dos cultivos convencional e orgânico. Semina: Ciências Agrárias, 33(5), 1855-1868.

Soares, D. J., Tavares, T. M., Brasil, I. M., Figueiredo, R. W., \& Sousa, P. H. (2012b). Processos oxidativos na fração lipídica de alimentos. Boletim CEPPA, 30(2), 263-272.

Toschi, T. G., Caboni, M. F., Penazzi, G., Lercker, G., \& Capella, P. (1993). A study on cashelw nut oil composition. Journal of the American Oil Chemists' Society, 70(10), 1017-1020. http://dx.doi. org/10.1007/BF02543029.

Zadernowskl, R., Nowak-Polakowska, H., \& Rashed, A. A. (1999). The influence of heat treatament on the activity of lipo and hydrophilic components of oat grain. Journal of Food Processing and Preservation, 33(3), 177-191. http://dx.doi.org/10.1111/j.1745-4549.1999.tb00378.x.

Zuniga, A. D. G., Coelho, A. F. S., Ferreira, E. M. S., Resende, E. A., \& Almeida, K. N. (2011). Avaliação da vida de prateleira de biscoito de castanha de caju tipo integral. Revista Brasileira de Produtos Agroindustriais, 13(3), 251-256. http://dx.doi.org/10.15871/15178595/rbpa.v13n3p251-256. 